Pak. j. sci. ind. res. Ser. B: biol. sci. 201457 (3) 117-122

\title{
Effect of Tank Mixed Application of Ammonium Sulphate and Carfentrazone-Ethyl + Clodinafop-Propargyl + Metsulfuron-Methyl on Weeds and Yield of Wheat
}

\author{
Asif Tanveer*, Adnan Khalid, Muhammad Tahir and Muhammad Ather Nadeem \\ Department of Agronomy, University of Agriculture, Faislabad, Pakistan
}

(received December 19, 2013; revised July 1, 2014; accepted August 27, 2014)

\begin{abstract}
Weeds are serious problem in wheat crop. The adjuvants are used to increase the weed control spectrum of herbicide or to reduce the dose of herbicide without affecting weed control efficiency. The effect of tank mixed application of ammonium sulphate and carfentrazone-ethyl + clodinafop-propargyl + metsulfuron-methyl on weeds of wheat (Triticum aestivum L.) was investigated under field conditions. The experiment comprised of carfentrazone-ethyl + clodinafop-propargyl+metsulfuron-methyl@ @50, $375 \mathrm{~g} /$ ha alone and with $1 \%$ and $2 \%$ ammonium sulphate solution. The maximum reduction in weed density $(97.29 \%)$ and dry weight $(94.27 \%)$ was recorded with carfentrazone-ethyl + clodinafop-propargyl + metsulfuron-methyl @ 500 g/ha. The grain yield and yield components of wheat were affected significantly, by treatments. Maximum grain yield was obtained with carfentrazone-ethyl + clodinafop-propargyl + metsulfuron-methyl @ 500 g/ha. This treatment resulted in $37.71 \%$ more grain yield over weedy check. Addition of $1-2 \%(\mathrm{wt} / \mathrm{v})$ ammonium sulphate did not enhance the activity of herbicide. Based on present study, it is concluded that use of ammonium sulphate adjuvants did not increase the efficiency of carfentrazone-ethyl + clodinafop-propargyl + metsulfuron-methyl.
\end{abstract}

Keywords: wheat, herbicide, adjuvant, ammonium sulphate, weeds

\section{Introduction}

In addition to many other factors, the low yield of wheat is attributed to serious weed infestation. Losses due to weeds have been reported from 18 to $30 \%$ (Ashiq and Cheema, 2005). In Pakistan, major weeds of wheat that cause huge economic losses are broad leaf dock (Rumex dentatus L.), swine cress (Coronopus didymus L.), emex species (Emex spinosa L.), canary grass (Phalaris minor Retz.), wild oat (Avena fatua L.), fumitory (Fumaria indica L.), lamb's quarters (Chenopodium album L.), field bindweed (Convolvulus arvensis L.), blue pimpernel (Anagallis arvensis L), and bermuda grass (Cynodon dactylon L.), (Tanveer and Ali, 2003).

Due to high competitive ability and high reproductive potential of weeds, it is imperative to check their infestation (Rehman et al., 2010). Weeds problem is getting from bad to worse in wheat sown under irrigated conditions. Cropping intensity is rapidly increasing and it is impossible to control weeds with traditional method such as Dab (suicidal germination) and hand weeding. Now a days chemical weed control is preferred because

*Author for correspondence;

E-mail: drasiftanveeruaf@hotmail.com it is rapid, convenient, inexpensive and more effective (Naseer-ud-Din et al., 2011). Marwat et al. (2003) reported that chemical weed control decreased the weed infestation and increased the yield of wheat. Postemergence herbicides are generally, absorbed through leaves. Leaf cuticle is composed of waxes and cutin that affect the herbicide absorption. The use of an adjuvant in combination with herbicide enhances the herbicide retention and leaf surface penetration through cuticle thereby, keeping the herbicide contact with plant tissues rather than edging up and rolling off and thus increases the phytotoxicity of herbicide (Zadorozhny, 2004). Adjuvants may also improve herbicide efficacy so that the concentration or total amount of herbicide required to achieve a given effect is reduced. Ammonium sulphate has many beneficial effects e.g., acts as a buffering agent, improves pesticide activity in hard water, increase efficacy of herbicide and enhances herbicide activity under stress conditions (Hatzios and Penner, 1985).

FMC X-100 herbicide is a combination of three active ingredients namely carfentrozone-ethyl, clodinafoppropargyl and metsulfuron-methyl. All these are applied 
as a foliar spray to control broadleaf, sedges and grass weeds and are absorbed through the leaves. Ammonium sulphate is a relatively inexpensive additive for herbicides. The objective of this study was to determine whether ammonium sulphate as an adjuvant can enhance herbicide effectiveness for weed control.

\section{Materials and Methods}

The present study was carried out at agronomy research area, University of Agriculture, Faisalabad, Pakistan, during winter 2011-12. The experiment was laid out in randomised complete block design (RCBD) having four replications with a net plot size of $6 \times 1.2 \mathrm{~m}$. The wheat cultivar "Sehar-2006" was grown in $20 \mathrm{~cm}$ apart rows with a single row hand drill using $150 \mathrm{~kg} / \mathrm{ha}$ seed rate. Seedbed was prepared by pulverising the soil with cultivator followed by planking. The fertiliser NPK was applied@100, 95, 75 kg/ha, respectively. Half dose of $\mathrm{N}$ and full dose of $\mathrm{P}$ and $\mathrm{K}$ was applied at the time of seedbed preparation, while remaining half dose of $\mathrm{N}$ was applied at the time of first irrigation. Uniform agronomic practices except treatments under study were applied to all entries of the experiment. Treatments consisted of control (weedy check), carfentrazone-ethyl + clodinafop-propargyl + metsulfuron-methyl @ 500, $375 \mathrm{~g} /$ ha alone and with $1 \%$ and $2 \%$ ammonium sulphate solution. The volume of spray was calibrated by spraying ordinary water on non-experimental area in the field. The herbicide carfentrazone-ethyl + clodinafoppropargyl + metsulfuron-methyl and $\mathrm{NH}_{2} \mathrm{SO}_{4}$ was applied as tank mixed postemergence spray after $1^{\text {st }}$ irrigation (35 days after sowing) with hand operated knap sack sprayer fitted with flat fan nozzle. Weeds density was recorded by counting the number of weeds 14 and 28 days after spray (DAS) and at harvest from an area of $1 \mathrm{~m}^{2}$ within the herbicide treated plots. Weeds were removed from ground surface and dried in an oven for $24 \mathrm{~h}$ at $70{ }^{\circ} \mathrm{C}$ and dry weight was recorded. Data on spike bearing tillers, number of grains per spike, 1000grain weight and grain yield were recorded by following standard procedure. Analysis of variance was carried out according to Fisher's analysis of variance technique (Steel et al., 1997) and least significance difference (LSD) test was used to compare the differences among treatments' means.

\section{Results and Discussion}

Total weeds density $\left(\mathrm{m}^{-2}\right)$. The analysis of the data showed that carfentrazone-ethyl + clodinafop-propargyl
+ metsulfuron-methyl alone and with ammonium sulphate as an adjuvant showed significant effect on weeds (Table 1). Maximum number of weeds (162.75, 188.0 and $166.25 \mathrm{~m}^{-2}$ ) was found in weedy check at 14 and 28 DAS and crop harvesting, respectively, which was significantly, higher than all other treatments under study. The significantly, minimum number of weeds $\left(11.00,5.50\right.$ and $\left.4.50 \mathrm{~m}^{-2}\right)$ was found in carfentrazoneethyl + clodinafop-propargyl + metsulfuron-methyl (a) $500 \mathrm{~g} / \mathrm{ha}$ with maximum weed control efficacy of $93.24 \%, 97.03 \%$ and $97.29 \%$ at 14 and 28 DAS and harvesting, respectively. The minimum weed control was found with carfentrazone-ethyl + clodinafoppropargyl+metsulfuron-methyl@ $500 \mathrm{~g} / \mathrm{ha}+2 \%$ $\mathrm{NH}_{2} \mathrm{SO}_{4}$ showing $85.41 \%, 88.96 \%$ and $87.81 \%$ weed control over weedy check at 14 and 28 DAS and harvesting, respectively. The weed count was decreased at final harvest and this decrease can be attributed to the mortality of the weeds after completing their life

Table 1. Effect of herbicide dose and ammonium sulphate as an adjuvant on total weed density $\left(\mathrm{m}^{-2}\right)$ and dry weight $\left(\mathrm{g} / \mathrm{m}^{2}\right)$

\begin{tabular}{|c|c|c|c|c|c|}
\hline \multicolumn{2}{|c|}{ Treatments } & \multicolumn{3}{|c|}{ Total weed density } & \multirow[b]{2}{*}{$\begin{array}{l}\text { Dry } \\
\text { weight } \\
\left(\mathrm{g} / \mathrm{m}^{2}\right)\end{array}$} \\
\hline $\begin{array}{l}\text { Herbicide } \\
\text { Carfentrazone- } \\
\text { ethyl + clodina- } \\
\text { fop-propargyl + } \\
\text { metsulfuron- } \\
\text { methyl } \\
(\mathrm{g} / \mathrm{ha})\end{array}$ & $\begin{array}{l}\frac{\text { Adjuvant }}{\mathrm{NH}_{2} \mathrm{SO}_{4}} \\
(\%)\end{array}$ & 14 DAS & $28 \mathrm{DAS}$ & $\begin{array}{l}\text { At } \\
\text { harvest }\end{array}$ & \\
\hline Weedy check & $\ldots \ldots$ & $162.75^{\mathrm{a}}$ & $188.00^{\mathrm{a}}$ & $166.25^{\mathrm{a}}$ & $86.40^{\mathrm{a}}$ \\
\hline 500 & $\ldots \ldots$ & $\begin{array}{l}11.00^{\mathrm{d}} \\
(93.24)\end{array}$ & $\begin{array}{l}5.50^{\mathrm{d}} \\
(97.07)\end{array}$ & $\begin{array}{l}4.50^{\mathrm{e}} \\
(97.29)\end{array}$ & $\begin{array}{l}4.95^{\mathrm{d}} \\
(94.27)\end{array}$ \\
\hline 375 & $\ldots \ldots$ & $\begin{array}{l}23.00^{\mathrm{b}} \\
(85.87)\end{array}$ & $\begin{array}{l}17.00^{\mathrm{bc}} \\
(90.96)\end{array}$ & $\begin{array}{l}16.25^{\mathrm{c}} \\
(90.22)\end{array}$ & $\begin{array}{l}13.80^{\mathrm{bc}} \\
(84.02)\end{array}$ \\
\hline 500 & 1 & $\begin{array}{l}23.25^{\mathrm{b}} \\
(85.71)\end{array}$ & $\begin{array}{l}19.75^{\mathrm{b}} \\
(89.49)\end{array}$ & $\begin{array}{l}19.00^{\mathrm{bc}} \\
(88.57)\end{array}$ & $\begin{array}{l}16.95^{\mathrm{b}} \\
(80.38)\end{array}$ \\
\hline 500 & 2 & $\begin{array}{l}23.75^{\mathrm{b}} \\
(85.41)\end{array}$ & $\begin{array}{l}20.75^{\mathrm{b}} \\
(88.96)\end{array}$ & $\begin{array}{l}20.25^{\mathrm{b}} \\
(87.81)\end{array}$ & $\begin{array}{l}13.15^{\mathrm{bc}} \\
(84.78)\end{array}$ \\
\hline 375 & 1 & $\begin{array}{l}17.50^{\mathrm{c}} \\
(89.25)\end{array}$ & $\begin{array}{l}12.25^{\mathrm{c}} \\
(93.48)\end{array}$ & $\begin{array}{l}12.25^{\mathrm{d}} \\
(92.63)\end{array}$ & $\begin{array}{l}11.85^{\mathrm{c}} \\
(86.28)\end{array}$ \\
\hline 375 & 2 & $\begin{array}{l}23.50^{\mathrm{b}} \\
(85.56)\end{array}$ & $\begin{array}{l}19.00^{\mathrm{b}} \\
(89.89)\end{array}$ & $\begin{array}{l}18.25^{\mathrm{bc}} \\
(89.02)\end{array}$ & $\begin{array}{l}15.15^{\mathrm{bc}} \\
(82.46)\end{array}$ \\
\hline LSD value & & 4.007 & 6.193 & 3.365 & 4.925 \\
\hline
\end{tabular}

Any two means sharing same letters did not differ significantly, at $5 \%$ level of probability; Figs. in parentheses showed \% decrease over weedy check; DAS = days after spray. 
span. Maximum population in weedy check was due to uncontrolled growth of weeds. Minimum number of weeds in control treatments was due to effect of herbicide. These results are confirmed by those of Shehzad et al. (2012) and Kumar et al. (2011), who reported that herbicides significantly control the weeds of wheat against weedy check. The non-significant effect of the adjuvant with full dose of herbicide can be attributed to the fact that adjuvants may have no effect on efficacy of herbicides if not used at proper rate (Tu et al. 2001) and even the effects of the adjuvants vary with concentration (Pacanoski, 2010). The non-significant effects of adjuvant on weed control had also been reported by O' Sullivum and Bonw' (1997). However, the addition of adjuvant with reduced herbicide dose resulted in lower total weed density than use of herbicide alone at same dose. Nadeem et al. (2008) also reported increase in herbicide efficacy against weeds with the addition of urea as an adjuvant. The non-significant effect of ammonium sulphate as an adjuvant at higher doses and pronounced effect at lower doses are supported by the findings of Bradley et al. (2000).

Individual weed density. Analysis of the data showed that carfentrazone-ethyl + clodinafop-propargyl + metsulfuron-methyl alone and with ammonium sulphate significantly, reduced the $P$. minor, C. album, C. didymus and $C$. arvensis population. The data given in Table 2 showed that maximum number of $P$. minor, C. album, $C$. didymus and $C$. arvensis was recorded in weedy check plots at 14 and 28 DAS, respectively, which was significantly higher than all other treatments under study. The minimum number of $P$. minor $\left(5.75\right.$ and $\left.1.25 \mathrm{~m}^{-2}\right)$, C. album $\left(0.25\right.$ and $\left.0.50 \mathrm{~m}^{-2}\right), C$. didymus $(0.50$ and $\left.0.50 \mathrm{~m}^{-2}\right)$ and $C$. arvensis $\left(0.25\right.$ and $\left.1.00 \mathrm{~m}^{-2}\right)$ was found in carfentrazone-ethyl + clodinafop-propargyl + metsulfuron-methyl@500 g/ha at 14 and 28 DAS, respectively. The respective values for percent weed control were $72.29 \%$ and $96.35 \% ; 99.21 \%$ and 97.96 $\%$; $98.46 \%$ and $98.64 \%$; and $95 \%$ and $80.95 \%$ over weedy check. Carfentrazone-ethyl + clodinafop-propargyl + metsulfuron-methyl@500 g/ha was statistically at par with all other weed control treatments in respect of $P$. minor, C. album and C. didymus control. Maximum population in weedy check was due to uncontrolled growth of weeds. Minimum number of weeds in weed control treatments could be attributed to more weed mortality due to the blocking of the electron transport system resulting in destruction of the PS-II reaction

Table 2. Effect of herbicide dose and ammonium sulphate as an adjuvant on individual weed density $\left(\mathrm{m}^{-2}\right) 14$ and 28 DAS.

\begin{tabular}{|c|c|c|c|c|c|c|c|c|c|}
\hline \multicolumn{2}{|l|}{ Treatments } & \multicolumn{8}{|c|}{ Individual weeds } \\
\hline Herbicide & Adjuvant & Phalaris & minor & Chenopo & dium album & Coronop & us didymus & Convolve & lus arvensis \\
\hline metsulfuron-methyl & & 14 DAS & $28 \mathrm{DAS}$ & 14 DAS & 28 DAS & 14 DAS & $28 \mathrm{DAS}$ & 14 DAS & $28 \mathrm{DAS}$ \\
\hline Weedy check & $\ldots$ & $20.75^{\mathrm{a}}$ & $34.25^{\mathrm{a}}$ & $31.25^{\mathrm{a}}$ & $24.50^{\mathrm{a}}$ & $32.50^{\mathrm{a}}$ & $36.75^{\mathrm{a}}$ & $5.00^{\mathrm{a}}$ & $5.25^{\mathrm{a}}$ \\
\hline 500 & $\ldots$ & $\begin{array}{l}5.75^{\mathrm{b}} \\
(72.29)\end{array}$ & $\begin{array}{l}1.25^{\mathrm{c}} \\
(96.35)\end{array}$ & $\begin{array}{l}0.25^{\mathrm{b}} \\
(99.21)\end{array}$ & $\begin{array}{l}0.50^{\mathrm{b}} \\
(97.96)\end{array}$ & $\begin{array}{l}0.50^{\mathrm{b}} \\
(98.46)\end{array}$ & $\begin{array}{c}0.50^{\mathrm{c}} \\
(98.64)\end{array}$ & $\begin{array}{l}0.25^{\mathrm{c}} \\
(95)\end{array}$ & $\begin{array}{l}1.00^{\mathrm{b}} \\
(80.95)\end{array}$ \\
\hline 375 & $\ldots$ & $\begin{array}{l}7.75^{\mathrm{b}} \\
(62.65)\end{array}$ & $\begin{array}{l}4.00^{b} \\
(88.32)\end{array}$ & $\begin{array}{l}1.50^{\mathrm{b}} \\
(95.24)\end{array}$ & $\begin{array}{l}1.50^{\mathrm{b}} \\
(93.88)\end{array}$ & $\begin{array}{l}1.50^{\mathrm{b}} \\
(95.38)\end{array}$ & $\begin{array}{l}1.75^{b c} \\
(95.24)\end{array}$ & $\begin{array}{l}1.00^{\mathrm{bc}} \\
(80)\end{array}$ & $\begin{array}{l}2.00^{b} \\
(61.90)\end{array}$ \\
\hline 500 & 1 & $\begin{array}{l}7.00^{\mathrm{b}} \\
(66.26)\end{array}$ & $\begin{array}{l}4.00^{\mathrm{b}} \\
(88.32)\end{array}$ & $\begin{array}{c}1.50^{\mathrm{b}} \\
(95.24)\end{array}$ & $\begin{array}{l}1.50^{\mathrm{b}} \\
(93.88)\end{array}$ & $\begin{array}{l}2.00^{\mathrm{b}} \\
(93.85)\end{array}$ & $\begin{array}{l}1.75^{\mathrm{bc}} \\
(95.24)\end{array}$ & $\begin{array}{l}1.50^{\mathrm{b}} \\
(70)\end{array}$ & $\begin{array}{l}1.50^{\mathrm{b}} \\
(71.43)\end{array}$ \\
\hline 500 & 2 & $\begin{array}{l}8.25^{\mathrm{b}} \\
(60.24)\end{array}$ & $\begin{array}{l}3.50^{\mathrm{bc}} \\
(89.78)\end{array}$ & $\begin{array}{l}1.75^{\mathrm{b}} \\
(94.44)\end{array}$ & $\begin{array}{l}2.00^{\mathrm{b}} \\
(91.84)\end{array}$ & $\begin{array}{l}1.25^{\mathrm{b}} \\
(96.16)\end{array}$ & $\begin{array}{l}2.50^{\mathrm{b}} \\
(93.16)\end{array}$ & $\begin{array}{l}1.25^{\mathrm{bc}} \\
(75)\end{array}$ & $\begin{array}{l}1.75^{\mathrm{b}} \\
(68.29)\end{array}$ \\
\hline 375 & 1 & $\begin{array}{l}6.00^{\mathrm{b}} \\
(71.08)\end{array}$ & $\begin{array}{l}3.75^{\mathrm{b}} \\
(89.05)\end{array}$ & $\begin{array}{l}0.50^{\mathrm{b}} \\
(98.41)\end{array}$ & $\begin{array}{l}0.75^{\mathrm{b}} \\
(96.24)\end{array}$ & $\begin{array}{l}1.25^{\mathrm{b}} \\
(96.16)\end{array}$ & $\begin{array}{l}0.75^{\mathrm{c}} \\
(97.96)\end{array}$ & $\begin{array}{l}0.75^{\mathrm{bc}} \\
(85)\end{array}$ & $\begin{array}{l}2.00^{b} \\
(61.90)\end{array}$ \\
\hline 375 & 2 & $\begin{array}{l}7.00^{\mathrm{b}} \\
(66.26)\end{array}$ & $\begin{array}{l}4.50^{\mathrm{b}} \\
(86.86)\end{array}$ & $\begin{array}{l}1.75^{\mathrm{b}} \\
(94.44)\end{array}$ & $\begin{array}{l}1.00^{\mathrm{b}} \\
(95.92)\end{array}$ & $\begin{array}{l}1.50^{\mathrm{b}} \\
(95.38)\end{array}$ & $\begin{array}{l}1.50^{\mathrm{bc}} \\
(95.92)\end{array}$ & $\begin{array}{l}1.25^{\mathrm{bc}} \\
(75)\end{array}$ & $\begin{array}{l}2.50^{\mathrm{b}} \\
(52.38)\end{array}$ \\
\hline LSD value & & 2.705 & 2.407 & 1.976 & 2.247 & 2.885 & 1.615 & 2.278 & 2.278 \\
\hline
\end{tabular}

Any two means sharing same letters did not differ significantly at 5\% level of probability; Figs. in parentheses showed $\%$ decrease over weedy check. 
centre, the already known mode of action of herbicide. These results are confirmed by those of Chhokar et al. (2006) and Khan et al. (2003), who reported that herbicides significantly control narrow and broad leaf weeds of wheat over untreated check.

The addition of adjuvant at both herbicides rates and adjuvant concentrations resulted in statistically similar density of all the weeds under study. Non-significant effect of ammonium sulphate on the efficacy of glyphosate had also been reported by Faircloth et al. (2004). The results are however contradictory to those reported by Nadeem et al. (2008), who reported significant decrease in weed density with the addition of urea as an adjuvant. The contradiction in results can be attributed to the differences in adjuvant and herbicide used.

Dry weed biomass $\left(g / \mathrm{m}^{2}\right)$. Analysis of the data showed that there was a significant effect of carfentrazone-ethyl + clodinafop-propargyl + metsulfuron-methyl alone and with ammonium sulphate as an adjuvant on dry weight of weeds at harvest (Table 1). Maximum dry weight of weeds $\left(86.40 \mathrm{~g} / \mathrm{m}^{2}\right)$ was found in weedy check. The minimum dry weight of weeds $\left(4.95 \mathrm{~g} / \mathrm{m}^{2}\right)$ was found in carfentrazone-ethyl + clodinafop-propargyl + metsulfuron-methyl@500 g/ha. Maximum reduction in weeds biomass was due to the herbicide. The differences in weed biomass can be attributed to the differences in weed density due to various treatments. These results are in conformity with those of El-Metwally et al. (2010) and Arif et al. (2004), who reported that herbicide decreased the fresh and dry weight of weeds as compared to the weedy check. The addition of chemical additive ammonium sulphate did not influence the activity of herbicide compared with herbicide alone. The results appear to contradict the commonly accepted idea that adjuvants enhance herbicide efficacy by increasing its absorption (Zadorozhny, 2004) and can therefore, be used to reduce herbicide input in agricultural ecosystems (Pacanoski, 2010). Results of the present study suggest that ammonium sulphate as an adjuvant should not be relied upon to improve efficiency of carfentrazone-ethyl + clodinafoppropargyl + metsulfuron-methyl. Similar conclusions can also be drawn from O' Sullivum and Bonw (1997), who reported that addition of adjuvants have no significant effect on weed control in maize.

Yield components of wheat. The statistical analysis of the data showed that there was significant effect of carfentrazone-ethyl+clodinafop-propargyl + metsulfuron- methyl alone and with ammonium sulphate as an adjuvant on spike bearing tillers, number of grains per spike and 1000 grain weight (Table 3). Maximum values of these components $\left(364.50 \mathrm{~m}^{-2}, 46.25,46.94 \mathrm{~g}\right.$, respectively) were recorded in carfentrazone-ethyl + clodinafop-propargyl + metsulfuron-methyl @ 500 g/ha and was followed by the application of carfentrazoneethyl + clodinafop-propargyl + metsulfuron-methyl @ $375 \& 500 \mathrm{~g} / \mathrm{ha}$ along with adjuvant. These results are confirmed by those of Khan et al. (2008) who observed that better weed control increased the nutrients availability to the crop which ultimately increased the spike bearing tillers of wheat. Nadeem et al. (2008) stated that number of grains per spike of wheat increased as a result of postemergence herbicide application. The increase in 1000 grain weight was possibly due to better growth and development of crop plants which resulted in more grain weight assimilation. These results are in conformity by those of Naseer-ud-Din et al. (2011) who observed significantly, higher 1000 grain weight with chemical weed control in wheat.

Table 3. Effect of herbicide and ammonium sulphate as an adjuvant on yield and yield parameters of wheat

\begin{tabular}{|c|c|c|c|c|c|}
\hline \multicolumn{2}{|c|}{ Treatments } & \multicolumn{4}{|c|}{ Parameters } \\
\hline $\begin{array}{l}\text { Herbicide } \\
\text { Carfentrazone- } \\
\text { ethyl + clodina- } \\
\text { fop-propargyl + } \\
\text { metsulfuron- } \\
\text { methyl } \\
(\mathrm{g} / \mathrm{ha})\end{array}$ & $\begin{array}{l}\frac{\text { Adjuvant }}{\mathrm{NH}_{2} \mathrm{SO}_{4}} \\
(\%)\end{array}$ & $\begin{array}{l}\text { Spike } \\
\text { bearing } \\
\text { tillers } \\
\left(\mathrm{m}^{-2}\right)\end{array}$ & $\begin{array}{l}\text { No. of } \\
\text { grains } \\
\text { per } \\
\text { spike }\end{array}$ & $\begin{array}{l}1000- \\
\text { grain } \\
\text { weight } \\
(\mathrm{g})\end{array}$ & $\begin{array}{l}\text { Grain } \\
\text { yield } \\
(\mathrm{t} / \mathrm{ha})\end{array}$ \\
\hline Weedy check & $\ldots$ & $297.25^{\mathrm{d}}$ & $38.00^{\mathrm{d}}$ & $39.15^{\mathrm{d}}$ & $3.50^{\mathrm{d}}$ \\
\hline 500 & $\ldots$ & $364.50^{\mathrm{a}}$ & $46.25^{\mathrm{a}}$ & $46.94^{\mathrm{a}}$ & $\begin{array}{l}4.82^{\mathrm{a}} \\
(37.71)\end{array}$ \\
\hline 375 & $\ldots$ & $328.50^{\mathrm{bc}}$ & $41.50^{\mathrm{c}}$ & $41.87^{\mathrm{c}}$ & $\begin{array}{l}4.23^{b c} \\
(20.86)\end{array}$ \\
\hline 500 & 1 & $321.50^{\mathrm{c}}$ & $42.75^{b c}$ & $42.71^{b c}$ & $\begin{array}{l}4.16^{b c} \\
(18.86)\end{array}$ \\
\hline 500 & 2 & $323.50^{\mathrm{c}}$ & $41.75^{\mathrm{c}}$ & $42.42^{\mathrm{c}}$ & $\begin{array}{l}4.09^{b c} \\
(16.85)\end{array}$ \\
\hline 375 & 1 & $342.25^{\mathrm{b}}$ & $44.00^{\mathrm{b}}$ & $44.04^{\mathrm{b}}$ & $\begin{array}{l}4.44^{\mathrm{b}} \\
(26.85)\end{array}$ \\
\hline 375 & 2 & $320.50^{\mathrm{c}}$ & $41.75^{\mathrm{c}}$ & $41.75^{\mathrm{c}}$ & $\begin{array}{l}4.06^{\mathrm{c}} \\
(16)\end{array}$ \\
\hline LSD value & & 18.461 & 2.142 & 1.578 & 0.356 \\
\hline
\end{tabular}

Any two means sharing same letters did not differ significantly at $5 \%$ level of probability; Figs. in parentheses showed $\%$ increase over weedy check. 
The addition of adjuvant had no effect on the control of individual weeds and non-significant effect can be attributed to the dose of the adjuvant with the herbicide. The adjuvants are more effective at lower concentration and higher concentration may result in no or even toxic effect (Tu et al., 2001). The results are supported by the findings of O' Sullivum and Bonw (1997), who reported that addition of adjuvants had no significant effect on yield components of maize.

Grain yield/ha). Grain yield is a function of interaction of various yield components such as number of fertile tillers per unit area, number of grains per spike and 1000 grain weight. The data given in Table 3 showed that carfentrazone-ethyl + clodinafop-propargyl + metsulfuron-methyl at various rates with ammonium sulphate as an adjuvant showed significant effect on grain yield. Maximum grain yield (4.82 t/ha) was recorded in carfentrazone-ethyl + clodinafop-propargyl +metsulfuron-methyl@500 g/ha, which was 37.71\% more than weedy check. The minimum grain yield $(3.50 \mathrm{t} / \mathrm{ha})$ was recorded in weedy check. Higher grain yield resulted from more number of spike bearing tillers, number of grains per spike and 1000 grain weight. These results are confirmed by El-Metwally et al. (2010) and Singh et al. (2006), who reported that application of postemergence herbicides increases the grain yield of wheat. The nonsignificant differences with the addition of ammonium sulphate as an adjuvant are supported by the findings of Faircloth et al. (2004). The results are however, in contrast with those of Nadeem et al. (2008) who reported significant increase in grain yield of maize with the use of urea as an adjuvant. The differences in results can be attributed to the different types of herbicides, adjuvants and crops used in the studies.

\section{Conclusion}

It can be concluded that carfentrazone-ethyl + clodinafoppropargyl+metsulfuron-methyl @ 500 g/ha with no supplemental adjuvant performed best in reducing weeds density, biomass and increasing grain yield and yield components of wheat. Based on present findings it is recommended that ammonium sulphate should not be used as an adjuvant with carfentrazone-ethyl + clodinafoppropargyl + metsulfuron-methyl.

\section{References}

Arif, M., Awan, I.U., Khan, H.H.U. 2004. Weed management strategies in wheat (Triticum aestivum L.). Pakistan Journal of Weed Science Research, 10: 11-16.
Ashiq, M., Cheema, Z.A. 2005. Effective Use of Herbicides, Weed Science Allelopathy Laboratory, University of Agriculture, Faisalabad, Pakistan.

Bradley, P.R., Johnson W.G., Smeda R.J. 2000. Response of sorghum (Sorghum bicolor) to atrazine, ammonium sulphate and glyphosate. Weed Technology, 14: $15-18$.

Chhokar, R.S., Sharma, R.K., Chauhan, D.S., Mongia, A.D. 2006. Evaluation of herbicides against Phalaris minor in wheat in north-western Indian plains. Weed Research, 46: 40-49.

El-Metwally, I.M., Abd El-Salam, M.S., Tagour, R.M. H. 2010. Nitrogen fertilizer levels and some weed control treatments effects on barley and associated weeds. Agricultural and Biological Journal of North America, 1: 992-1000.

Faircloth, W.H., Monks, C.D., Patterson, M.G., Wentze, G.R., Delaney, D.P, Sanders, J.C. 2004. Cotton and weed response to glyphosate application with sulfur containing additives. Weed Technology, 18: 404-411.

Hatzios, K.K., Penner, D. 1985. Interactions of herbicides with other agrochemicals in higher plants. Reviews of Weed Science, 1: 1-63.

Khan, IA., Hassan, G., Marwat, K.B., Daur, I. 2008. Efficacy of some pre and post emergence herbicides on yield and yield components of canola. Pakistan Journal of Botany, 40: 1943-1947.

Khan, M.H., Hassan, G., Khan, N., Khan, M.A. 2003. Efficacy of different herbicides for controlling broadleaf weeds in wheat. Asian Journal of Plant Sciences, 2: 254-256.

Kumar, S., Angiras, N.N., Rana, S.S. 2011. Bio-efficacy of clodinafop-propargyl + metsulfuron methyl against complex weed flora in wheat. Indian Journal of Weed Science, 43: 195-198.

Marwat, M.I., Ahmad, H.K., Marwat, K.B., Hassan, G. 2003. Integrated weed management in wheat-III tillers $\mathrm{M}^{-2}$, productive tiller $\mathrm{M}^{-2}$, spikelets spike, grain spike ${ }^{-1}, 1000$ grain weight and grain yield. Pakistan Journal of Weed Science Research, 9: 23-31.

Naseer-ud-Din, G.M., Shehzad, M.A., Nasrullah, H.M. 2011. Efficacy of various pre and post-emergence herbicides to control weeds in wheat. Pakistan Journal of Agricultural Sciences, 48: 185-190.

Nadeem, M.A., Ahmad, R., Khalid, M., Naveed, M., Tanveer, A., Ahmad, J.N. 2008. Growth and yield response of autumn planted maize (Zea mays L.) and its weeds to reduced doses of herbicide application in combination with urea. Pakistan 
Journal of Botany, 40: 667-676.

Pacanoski, Z. 2010. Role of adjuvants on herbicide behavior: a review of different experiences. Herbologia, 11: 67-79.

O' Sullivan, J., Bonw, W.J. 1997. Effects of timing and adjuvants on the efficacy of reduced herbicides rates for sweet corn (Zea mays). Weed Technology, 11: 486-489.

Rehman, A., Cheema, Z.A., Khaliq, A., Arshad, M., Mohsan, S. 2010. Application of sorghum, sunflower and rice water extract combinations helps in reducing herbicide dose for weed management in rice. International Journal of Agriculture and Biology, 12: 901-906.

Shehzad, M.A., Nadeem, M.A., Iqbal, M. 2012. Weed control and yield attributes against post-emergence herbicides application in wheat crop, Punjab, Pakistan. Global Advanced Research Journal of Agricultural Science, 1: 007-016.

Singh, R., Dhiman, S., Rana, N.S., Kumar, S., Singh, V.K., Singh, R.G. 2006. Efficacy of dicamba alone and in combination with isoproturon on wheat
(Triticum aestivum L.) and associated weeds. Indian Journal of Agronomy, 51: 139-141.

Steel, R.G.D.,Torrie, J.H., Dickey, D. 1997. Principles and Procedures of Statistics: A Biometrical Approach, pp.172-177, $3^{\text {rd }}$ edition, McGraw Hill Book Co. Inc., New York, USA.

Tanveer, A., Ali, A. 2003. Weeds and Their Control, pp. 162, Higher Education Commission, Islamabad, Pakistan, Press Manager, H-9, Islamabad, Pakistan.

Tu, M., Hurd, C., Randall, J.M. 2001. The Nature Conservancy, Weed Control Methods Handbook: Tools and Techniques for Use in Natural Areas, 533 pp., Wild and Invasive Species Team, Centre for Invasive Species and Ecosystem Health, University of Gorgia, USA.

Zadorozhny, V. 2004. Herbicide based strategies for maize to prevent development of resistance in weeds in Ukraine. In: Proceedings of $14^{\text {th }}$ Australian Weed Conference, Weed Management: Balancing People, Planet, Profit, B. M. Sindel and S. B. Johnson (eds.), pp. 290-293, Wagga, Wagga, New South Wales Australia. 